\title{
Expenditure Elasticities of the Demand for Leisure Services
}

\author{
Tim Pawlowski ${ }^{\dagger}$ and Christoph Pawlowski ${ }^{\dagger \dagger}$
}

October 2010

\begin{abstract}
Although some research has already focused on the analysis of expenditure elasticities of leisure demand, some shortcomings with regard to the content and the underlying theoretical model as well as the applied methods exist. This paper aims at avoiding these problems to provide consistent derivatives of leisure service expenditure elasticities. Therefore, a regular demand system is derived from microeconomic duality theory. To implement leisure specific demand factors (i.e., demand- and supply-based sports and recreational opportunities as well as sports and recreational preferences) while still being consistent with neoclassical demand theory, the basic model is extended by applying the demographic translation framework. Data of the continuous household budget survey $(n=7,724)$ from Germany is used for the estimation of the derived demand system. It is shown how sensitive the results are depending on the applied (censored) regression model: 16 out of 18 analyzed services are indicated as luxury goods based on the findings of the Tobit model type I but as necessities based on the findings of the Tobit model type II. Possible implications are presented and discussed.
\end{abstract}

JEL Classification Codes: D01, D12, L83

Key Words: Expenditure elasticity, demand, services, Tobit, Almost Ideal Demand System

${ }^{\dagger}$ Institute of Sport Economics and Sport Management, German Sport University Cologne, Institutsgebäude II, EG, Raum 5, Am Sportpark Müngersdorf 650933 Cologne, Germany, Phone: +49-221-4982-6098, Fax: +49-221-4982-8141, pawlowski@dshs-koeln.de

${ }^{\dagger \dagger}$ Institute of Sport Economics and Sport Management, German Sport University Cologne Institutsgebäude II, EG, Raum 5, Am Sportpark Müngersdorf 650933 Cologne, Germany, Phone: +49-221-4982-6095, Fax: +49-221-4982-8144, breuer@ dshs-koeln.de 


\section{INTRODUCTION}

Demand elasticities are non-dimensional measures that indicate the sensitivity of demand to variations in a particular economic and non-economic factor (Downward, Dawson, and Dejonghe, 2008; Jones, 2004). Knowledge of the values of certain elasticities is of great importance to management since they can inform strategic and operational marketing decisions (Samuelson and Nordhaus, 2001). Amongst others, the price (Lindberg and Aylward, 1999), the cross price (Henningsen, 2006), and the income or expenditure elasticities (Salvatore, 2005) are the most significant elasticities in applied demand analysis. The latter serves as a categorization tool for products and services in luxuries or necessities. Based on this categorization, one might distinguish between growing and declining branches of products and services in the future (Gratton and Taylor, 1992).

Although some research has already focused on the analysis of income or expenditure elasticities for leisure demand, two major shortcomings exist: first, the studies are based on highly aggregated data with few management implications and the risk of ecological fallacies; second, many studies do not consider the censored sample problem in the context of demand analysis, which is important especially in the case of sport because lack of participation can be linked to zero expenditures. This paper aims at avoiding these shortcomings to provide consistent derivatives of leisure service expenditure elasticities. Two main contributions are offered, therefore.

First, to derive expenditure elasticities for a total of 18 leisure service categories based on a consistent theoretical demand model; second, to show how sensitive the results are depending on the applied (censored) regression model. 
The paper is structured as follows: first, there is a presentation of the state of research on the analysis of income effects on leisure service expenditure; second, we derive a comprehensive theoretical model for the demand analysis of leisure services; third, we move on to the definition of the data used in the current research and discuss the suitable methods and models to overcome the sample selection problem; fourth, there is a presentation of the results. Finally, the paper concludes with a discussion of the results and some ideas regarding further research directions.

\section{LITERATURE REVIEW}

There is a substantial literature that examines the expenditure elasticities in the leisure and tourism sectors. Blaine and Mohammad (1991) identify that the budget share for recreation-related goods and services increases with an increasing total outlay. Therefore, the recreation is indicated to be a luxury good $(\varepsilon=1.44)$. While the findings of an income elastic demand for this broad category is in line with the findings of Martin and Mason (1980), Moehrle (1990), Nelson (2001) and Sobel (1983), the latter detected product-related differences: following Sobel (1983), products of the category "visible success" (e.g. vacation expenditure, membership fees for clubs and organizations etc.) are luxuries $(\varepsilon>1)$ while products of the category "home life" (e.g. expenditure on television, camping, and health and sports equipment) are necessities $(0<\varepsilon<1)$. Furthermore, Nelson (2001) identified that the

demand for "live events" is income inelastic $(0<\varepsilon<1)$, and the Department of the Arts, Sport, the Environment, Tourism and Territories (1988), identified differences in the income elasticities between the households of different socioeconomic groups. Households with the 
head of household working as a miner $(\varepsilon=1.73)$ as well as households with three or more children $(\varepsilon=1.11)$ have an income elastic demand for sports and recreational products while households with the head of household working in the service sector $(\varepsilon=.82)$ as well as households with only one child $(\varepsilon=.94)$ show an income inelastic demand for the same products. Dardis, Soberon-Ferrer, and Patro (1994) examined the impact of different income components on the consumption expenditure on different goods. Even though they could detect that all the significant effects are positive, some category-specific differences exist: the salary of the head of household has only a significant impact on the consumption expenditure for "passive leisure" (e.g. expenditure on products and services for television, radio, and music) as well as "entertainment" (e.g. entrance fees for sport events, theaters, or museums). In contrast, the salary of the marriage partner has only a significant impact on the consumption expenditure on "active leisure" (e.g. expenditure on sports, fishing, or photography) while other income components have a significant impact on all three expenditure categories.

Further, Blundell, Browning, and Meghir (1994) identified that services are luxuries ( $\varepsilon$ $=2.11$ ) in general, Gundlach (1993) found out that this holds true only for cross-section data. His analysis of time series data reveals that the broad category containing all services tends to be a necessity. Concerning tourism, Papanikos and Sakellariou (1997) found country-specific differences, such that the Japanese demand for services is inelastic for outgoing tourism to the Philippines $(\varepsilon=.68)$, it is elastic for outgoing tourism to Malaysia $(\varepsilon=1.19)$. In a meta analysis of tourism demand, Crouch detected a greater spread in the income elasticities for general tourism demand ranging from $\varepsilon=.28$ (outgoing tourism to Latin America) to $\varepsilon=4.45$ (outgoing tourism to developing countries in Asia). Cai, Hong, and Morrison (1995), identified a significant positive relationship between income and the expenditure on 
entertainment, sport events, museums, and tours, whilst Paulin (1990) detected an increasing expenditure share for entertainment services on travelling. This is confirmed by Pyo, Uysal, and McLellan (1991).

In summary, income is the most often analyzed demand factor. With few exceptions (Legohérel and Hong, 2006; Leones, Colby, and Crandall, 1998; van Ophem and Hoog, 1994), all the studies confirm a significant positive relationship between income and expenditure, which means that the expenditure elasticities for the analyzed services are positive. Nevertheless, it remains ambiguous whether the portion of leisure expenditure in relation to the total outlay is decreasing indicating necessity goods (Euler, 1990, $0<\varepsilon<1$ ), constant (Loy and Rudman, 1983, $\varepsilon=1$ ), or increasing indicating luxury goods (Wagner and Washington, $1982, \varepsilon>1)$.

\section{THEORETICAL MODEL}

Neoclassical demand theory shows that the demand for goods and services by a household can be derived either from utility maximization (the primal approach) or cost minimization (the dual approach).

Following the primal approach the behavior of a household is rational if the perceived utility of a bundle of goods and services is at least as high as the perceived utility of any of the other bundles of goods and services available with the household's budget. Therefore, the

ideal consumption plan and, respectively, the household's demand functions for certain goods and services can be derived from utility maximization subject to the household's budget constraint with the Lagrange approach (see figure 1). 
Insert figure 1 about here

Alternatively in the dual approach the behavior of a household is also rational if the household selects goods to minimize the outlay in order to reach a certain utility level. In this case, the ideal consumption plan and, respectively, the household's demand functions for a bundle of certain goods and services can be derived from cost minimizing subject to a certain utility level with the Lagrange approach. The possibility of backward calculation is of particular interest for general demand analyses: Hicksian demand functions can be derived from the cost function and Marshallian demand functions can be derived from the indirect utility function (Deaton and Muellbauer, 1999). Such a system of demand functions automatically satisfies the general restrictions of demand theory (homogeneity, adding up, symmetry, non-negativity) and is called a regular demand system (Phlips, 1983). With the Linear Expenditure System (LES), it was possible to estimate a regular demand system for the first time (Geary, 1950-1951; Klein and Rubin, 1947-1948; Stone, 1954). However, the LES is based on some restrictive assumptions: beside the additive utility function (which suggests that the utility of a certain good only depends on the consumed quantity of this good and not on any other good), the resulting constant income elasticities are extremely unrealistic (Deaton and Muellbauer, 1999). In the course of time, new and more flexible demand systems were developed and empirically verified. The most popular model that is based on a flexible cost function is the Almost Ideal Demand System (AID System) by Deaton and Muellbauer (1980). The numerous empirical estimations of the AID System, particularly in the recent past (Eakins and Gallagher, 2003; Katchova and Chern, 2004; Matsuda, 2006), reflect the relevance of this 
model to applied demand analyses. The starting point for the derivation of the AID System is a specific cost function:

$$
c(\cdot)=e^{a(p)+U b(p)}
$$

The derivation and transformation of this specific form of the cost function leads to a system of $n$ equations, where the expenditure share of a good $i\left(w_{i}\right)$ is functionally linked to the prices of other goods $\left(p_{j}\right)$, the own price as an index $(P)$, and the income or total outlay $(W)$ :

$$
w_{i}=\alpha_{i}+\sum_{j=1}^{n} \gamma_{i j} \ln p_{j}+\beta_{i} \ln \left(\frac{W}{P}\right) \quad \text { for each } i=1,2, \ldots, n
$$

In the current context two particularities lead to a modification of the original expenditure share equations. The first is that because of data restrictions consumer behavior cannot be analyzed with respect to the prices of goods. Given that prices are constant, the demand system is reduced to a system of Engel curves. Therefore, the general restrictions related to the price (homogeneity, symmetry, non-negativity) disappear. The single remaining general restriction is the adding-up condition (Phlips, 1983). The AID System simplifies to (Missong, 2004):

$$
\begin{array}{ll}
w_{i}=\alpha_{i}^{*}+\beta_{i} \ln W & \text { for each } i=1,2, \ldots, n \\
\text { with } & \alpha_{i}^{*}=\alpha_{i}+\sum_{j=1}^{n} \gamma_{i j}-\beta_{i}
\end{array}
$$

Since the number of Engel curve parameters to be estimated $\left(\alpha_{i}^{*}, \beta_{i}\right)$ is smaller than the number of Engel curve coefficients derived from the demand system $\left(\alpha_{i}, \beta_{i}, \gamma_{i j}\right)$, the identification of the AID System is no longer possible. Nevertheless, the basic form known as the Working-Leser Model (WLM: Leser, 1963; Working, 1943) also satisfies the adding-up 
condition and therefore is in line with the neo-classical demand theory. The second peculiarity is that beside several critical aspects in general (Wolf, 2005), a purely neoclassical analysis building an explanation of demand primarily on prices and income is not sufficient for the leisure sector, because of other essential features of the demand for leisure. These include demand-based leisure opportunities (Bittman, 1999), leisure preferences (Gratton and Taylor 2000), and supply-based leisure opportunities (Cooke, 1994). Following Bittman (1999), demand-based leisure opportunities are constrained by disposable money and time. Therefore, households can experience alternative (high versus low) capacities to spend and (high versus low) levels of free time available based on the social status of the household's head (see figure 2).

Insert figure 2 about here

Furthermore, supply-based leisure opportunities, like the size of the city in which the household lives (degree of urbanization), can be expected to influence the demand for leisure services. Cooke (1994), for example, notes that the availability of transportation possibilities is an important factor in the demand for leisure services: a well-developed public transportation system or the existence of private vehicles enables or at least facilitates the access to certain leisure opportunities (e.g. the movies, indoor ski venue, theme park). Therefore, increasing mobility leads to an increasing number of leisure opportunities. On the other hand, difficulties of congestion (e.g. traffic jams) can exert a negative effect on the demand for leisure services. To implement these factors while still being consistent with neoclassical demand theory, the 
Working-Leser Model is extended by integrating the demographic translation framework (Pollak and Wales, 1992) with leisure-specific factors:

$$
w_{i}=q_{i 0}+\sum_{r=1}^{s} q_{i r} t_{r}+b_{i} \ln W \quad \text { for each } i=1,2, \ldots, n
$$

From a theoretical point of view, this functional form assumes that the additional factors, like the degree of urbanization $\left(t_{r}\right)$, have an impact on the constant term. In contrast, the sensitivity of the demand response to changes in the disposable income does not depend on the extent of these factors.

To derive the service-specific expenditure elasticities, the expenditure share equations have to be transformed into demand functions by multiplying with the total outlay $(W)$ (Blaas and Sieber, 2000).

$$
e_{i}=W w_{i}=W\left(\theta_{i 0}+\sum_{r=1}^{s} \theta_{i r} t_{r}+\beta_{i} \ln W\right) \quad \text { for each } i=1,2, \ldots, n
$$

The expenditure elasticities indicate the percentage change in the expenditure for a certain leisure service that will follow any given percentage change in the total outlay. Therefore, expenditure elasticities are the product of the first-order derivative and the quotient of total outlay to the expenditure for a certain leisure service:

$$
\varepsilon_{e_{i}, W}=\frac{\partial e_{i}(W)}{\partial W} * \frac{W}{e_{i}} \quad \text { for each } i=1,2, \ldots, n
$$

For Working-Leser demand functions, this is:

$$
e_{e_{i}, W}=\left[q_{i 0}+\sum_{r=1}^{s} q_{i r} t_{r}+b_{i} \ln W+b_{i} W \frac{1}{W}\right] * \frac{1}{w_{i}} \quad \text { for each } i=1,2, \ldots, n
$$

or 


$$
\varepsilon_{e_{i}, W}=\left[\left(\theta_{i 0}+\sum_{r=1}^{s} \theta_{i r} t_{r}+\beta_{i} \ln W\right)+\beta_{i}\right] * \frac{1}{w_{i}} \quad \text { for each } i=1,2, \ldots, n
$$

or

$$
\varepsilon_{e_{i}, W}=w_{i}+\beta_{i} * \frac{1}{w_{i}} \quad \text { for each } i=1,2, \ldots, n
$$

or

$$
\varepsilon_{e_{i}, W}=1+\frac{\beta_{i}}{w_{i}} \quad \text { for each } i=1,2, \ldots, n
$$

While the sensitivity of the demand response to changes in the disposable income does not depend on the extent of sociodemographic factors directly though, of course, in estimating $\beta_{\mathrm{i}}$ it depends on the certain budget share $\left(w_{i}\right)$. Therefore, it is possible to derive demographically scaled expenditure elasticities based on household-specific budget shares that might serve as an indicator of household-specific consumption patterns (Brosig, 2000). Furthermore, the value of the expenditure elasticities depends on the calculated coefficient of the logarithmized total outlay $\left(\beta_{i}\right)$.

\section{METHOD}

Following equation (10), to derive the category-dependent expenditure elasticities, the expenditure shares $\left(w_{i}\right)$ have to be calculated and the coefficients of the logarithmized total outlay $\left(\beta_{i}\right)$ have to be estimated. The methodological framework to derive the latter is described in the following chapters in detail. 


\section{Data and Estimator}

To derive the expenditure category-dependent elasticities, data from the continuous household budget survey (CHBS) from $2006(\mathrm{n}=7,724)$ is used. Since 2005, the CHBS as the quota sample has been based on the representative sample of the survey of household income and expenditure (SHIE). The characteristics used to select the households are: the type of household, the employment status of the head of household (yes/no), and the income class of the head of household. The sample of the CHBS data is extrapolated to the complete country (in analogy to the extrapolation of the SHIE data) by applying a specific extrapolation factor (Fleck and Papastefanou 2006).

In this study, we analyse a total number of 18 different leisure services from 3 different aggregation levels: beside the broadest category (leisure services: LEISURE), which is made up of the sports and recreational services (SPORT) as well as the cultural services (CULTURE), we have access to data for the following subcategories: sport event admission (EVENT), entrance fees for swimming pools (POOL), music lessons (MUSIC), dancing lessons (DANCE), fitness center fees (FITNESS), ski lift fees (SKI), sport club membership fees (CLUB), opera admission (OPERA), theater admission (THEATER), cinema admission (CINEMA), circus admission (CIRCUS), museum admission (MUSEUM), zoo admission (ZOO), fees for pay TV (PAYTV) and the rental of video films (FILM).

Although this study focuses on expenditure elasticities and therefore primarily on the relationship between (logarithmized) total outlay and budget shares, that is, the estimation of $\beta_{i}$, it is always desirable to estimate a complete model with all the factors that are supposed to influence the consumption expenditure (Backhaus et al., 2003). In order to take leisure- 
specific demand factors into account, the degree of urbanization (fewer than 20,000 inhabitants, 20,000-99,999 inhabitants, 100,000 and more inhabitants) and the area (northwest, northeast, south) where the household is located are included in the model. Furthermore, the reported quarter (January-March, April-June, July-September, OctoberDecember) and the age, the social status (public official, white-collar worker, blue-collar worker, unemployed person, retired person, student), the level of education (high-school diploma and higher), and the marital status (married, single) of the head of the household, as well as the structure of the household (children aged 6 years and under, children aged 6-18 years, children aged 18 years and above, number of people in the household) are included in the model.

Summing up, the expenditure shares of the $m$ leisure services serve as dependent variables and, along with the logarithmized total household expenditure and the leisure-specific factors as independent variables, make up a system of $m$ regression equations. As discussed below, a number of possible estimators can be used to analyse the data.

\section{Tobit Model Type I}

Since not all the households spent their income on all the leisure service items, numerous zero observations exist in the data and we are faced with the so-called censored sample problem. The censored sample problem is one of the most discussed problems in applied demand analysis and is mostly related to expenditure analysis (Barslund, 2007; Czarnitzki and Stadtmann,2002; Dardis et al., 1994; Deaton and Muellbauer, 1999; Lera-Lopéz and RapúnGárate, 2005; Lin, 2006; Long, 1997; Phlips, 1983; Shonkwiler and Yen, 1999; Thrane, 2001; 
Wooldridge, 2003). To avoid biased estimates (Pawlowski et al., 2009), the basic model has to be modified.

With his econometric study of durable goods, Tobin (1958) was the first to develop a modified concept of analyzing consumer demand and solving the censored sample problem. Following Tobin's approach (Tobit model type I; Amemiya, 1985), it is assumed that a latent variable that measures the consumer's propensity to spend money on a certain leisure service $\left(w_{h}^{*}\right)$ is in linear relation to a vector of influencing variables $\left(Z_{h}\right)$ and undetectable influences $\left(\varepsilon_{h}\right)$ :

$$
w_{h}^{*}=\beta Z_{h}+\varepsilon_{h}
$$

It is assumed that a household $h$ spends $\left(w_{h}^{*}\right)$ on a certain leisure service if the latent variable $\left(w_{h}^{*}\right)$ is positive. In contrast to the observed expenditure share of households $h\left(w_{h}\right)$, the value of the unobservable variable $\left(w_{h}^{*}\right)$ can be negative. For negative values of the latent variable, the household will not spend any money on the leisure service:

$$
w_{h}=\left\{\begin{array}{lll}
w_{h}^{*} & \text { if } & w_{h}^{*}>0 \\
0 & \text { if } & w_{h}^{*} \leq 0
\end{array}\right.
$$

In the next step, the likelihood function can be developed, which consists of two parts (Franz, 2006): the product of the probabilities that households do not spend any money on the certain leisure service $\left[\operatorname{Pr}=\left(w_{h}=0\right)\right]$ and the product of the probabilities that households spend $\left(w_{h}^{*}\right)$ on the leisure service $\left[\operatorname{Pr}=\left(w_{h}=w_{h}^{*}\right)\right]$ :

$$
L\left(\beta, \sigma_{e}\right)=\prod_{\text {censored }} \operatorname{Pr}\left(w_{h}=0\right) \prod_{\text {uncensored }} \operatorname{Pr}\left(w_{h}=w_{h}^{*}\right)
$$


Assuming standard normal distributed errors $\left(\varepsilon_{h}\right)$, the likelihood function (13) can be

rewritten using a probability density function $(\phi)$ and cumulative distribution function ( $\Phi)$ of the standard normal distribution:

$$
L\left(\beta, \sigma_{e}\right)=\prod_{\text {censored }} \Phi\left(\frac{0-Z_{h} \beta}{\sigma_{e}}\right) \prod_{\text {uncensored }} \frac{1}{\sigma_{e}} \phi\left(\frac{w_{h}-Z_{h} \beta}{\sigma_{e}}\right)
$$

Equation (14) can be estimated by applying the maximum likelihood (ML).

\section{Tobit Model Type II}

Following Tobin's approach, Heckman $(1974,1976,1979)$ developed an indirect (two-step) estimation of the relation of interest between the dependent variable and a vector of explaining variables. This so-called Tobit type II (Amemiya, 1985) or Heckit model allows researchers to examine both the qualitative decision (here: spending or non-spending) and the quantitative decision (here: expenditure share) separately. In the first stage, the qualitative decision on spending money or not is modeled with a binary dummy variable that takes the value one if the consumer is willing to spend money on the certain leisure service and zero if not:

$$
d_{h}=\left\{\begin{array}{lll}
1 & \text { if } & d_{h}^{*}>0 \\
0 & \text { if } & d_{h}^{*} \leq 0
\end{array}\right.
$$

Assuming a linear relationship as well as standard normal distributed error terms, the equation to be estimated in the first step could be described as follows:

$$
d_{h}^{*}=\beta^{1} Z_{h}^{1}+\varepsilon_{h}^{1}
$$


In the second stage, we could detect a positive value of the expenditure share $\left(w_{h}\right)$ if the money-spending decision in the first stage is positive:

$$
w_{h}=\left\{\begin{array}{lll}
w_{h}^{*} & \text { if } & d_{h}^{*}>0 \\
0 & \text { if } & d_{h}^{*} \leq 0
\end{array}\right.
$$

Again, under simplifying assumptions (linear relationship, standard normal distributed error terms), the equation to be estimated in the second stage could be described as follows (note that it is not necessary for $Z_{h}^{1}$ to equal $Z_{h}^{2}$ ):

$$
w_{h}^{*}=\beta^{2} Z_{h}^{2}+\varepsilon_{h}^{2}
$$

If $\left(\varepsilon_{h}^{1}\right)$ and $\left(\varepsilon_{h}^{2}\right)$ are correlated, ordinary least squares (OLS) estimation based only on uncensored observations would yield biased estimates $\left(\beta^{2}\right)$ since the conditional expected value of the error term $\left[E\left(\varepsilon_{h}^{2} \mid \varepsilon_{h}^{13}-\beta^{1} Z_{h}^{1}\right)\right]$ is neglected:

$$
E\left(w_{h} \mid Z_{h}^{2}, d_{h}=1\right)=\beta^{2} Z_{h}^{2}+E\left(\varepsilon_{h}^{2} \mid \varepsilon_{h}^{13}-\beta^{1} Z_{h}^{1}\right)
$$

Assuming standard normal distributed errors, equation (19) can be rewritten using a probability density function $(\phi)$ and a cumulative distribution function $(\Phi)$ of the standard normal distribution as well as a standard deviation of errors $(\sigma)$ and correlation of errors $(\rho)$ as follows:

$$
E\left(w_{h} \mid Z_{h}^{2}, d_{h}=1\right)=\beta^{2} Z_{h}^{2}+\kappa \lambda \quad \text { with } \lambda_{h}=\frac{\phi\left(\beta^{1} Z_{h}^{1} / \sigma_{\varepsilon^{1}}\right)}{\Phi\left(\beta^{1} Z_{h}^{1} / \sigma_{\varepsilon^{1}}\right)}
$$

By applying the two-step estimation procedure, it is possible to specify consistent estimators $\left(\beta^{2}\right)$ : (1) in a first step, the probit model is estimated by applying the ML to all observations. 
The resultant estimators are used to calculate $\left(\lambda_{h}\right)$, which is known as the hazard rate or inverse Mill's ratio (IMR). (2) By applying OLS estimation only to uncensored observations in a second step, all the parameters $\left(\beta^{2}\right)$ can be estimated since all the individual hazard rates can be implemented as ordinary explanatory variables (note that the estimated coefficient $(\kappa)$ represents the product of $\left.\left(\sigma_{\varepsilon^{2}} \rho_{\varepsilon^{1} \varepsilon^{2}}\right)\right)$.

\section{Model Selection}

Contrary to Tobin's approach, with the separate estimation of the qualitative and the quantitative equations, the coefficients in the Tobit model type II are not constrained to be the same sign for both decisions (Weagley and Huh, 2004). Furthermore, zero observations do not have to be the result of corner solutions, which means that a sufficiently large change in explanatory variables would ultimately create a positive consumption expenditure for any given household (Verbeek, 2005). In this case, the Tobit model type II appears more flexible than the Tobit model type I. On the other hand, in contrast to the Tobit model type II, the researcher does not have to specify a priori identifying variables (variables in the vector of $Z_{h}^{1}$ that do not belong to the vector of $Z_{h}^{2}$ ) in the basic model by James Tobin. While no general agreement or guidance concerning the selection of the identifying variables exists, it is a crucial point and might heavily influence the estimation results (Verbeek, 2005). Therefore, both models are faced with certain advantages and limitations so that it is not possible to state a priori which one is best suited to this research context. 
While other single equation models (e.g. the double hurdle model) do not appear to be more appropriate from the theoretical point of view, it has to be discussed whether a multivariate Tobit model might be necessary. Such models are required if the qualitative and/or the quantitative decisions of a certain leisure service depend on the corresponding decisions concerning other leisure services. From a statistical point of view, this is the case if the error terms of two leisure services in the same stage are correlated. While this does not seem unrealistic (e.g. a general preference factor for or against sport might exist that is not part of the set of available independent variables), the development of adequate multivariate models is not satisfying: an approach developed by Heien and Wessells (1990) is not consistent while the model developed by Shonkwiler and Yen (1999) generates inefficient estimates (Tauchmann, 2005). However, since Halvorsen and Nesbakken (2004) find that stochastic interdependencies (e.g. a seemingly unrelated regression (SUR) in the second stage of the Tobit model type II) does not yield appreciable different estimates, our analysis is focused on the single equation approaches by Tobin and Heckman. To compare the results, we also present the subsample OLS estimation without correction of the sample selection. Applying the Tobit models types I and II, the estimated coefficients of total outlay $\left(\beta_{i}\right)$ also cover the effect of total outlay on the qualitative decision. Therefore, to derive the expenditure elasticities, we use the marginal effects instead of the estimated coefficient $\left(\beta_{i}\right)$ following the approaches of McDonald and Moffitt (1980) for the Tobit model type I and of Hoffmann and Kassouf (2005) for the Tobit model type II. For comparability reasons, the derived expenditure elasticities are conditional to such households with expenditure in the corresponding category. 


\section{RESULTS}

With more than 25 billion euros, German households spent around 3\% of their disposable budget on leisure services in 2006. Of the analyzed subcategories, CLUB with around 3.2 billion euros, MUSIC with more than 1.3 billion euros, and FITNESS with around 1.2 billion euros are the most significant ones. While nearly all of the participating households spent any money on leisure services (97.3\%), some subcategories exist where only a few households spent money (e.g. PAYTV: 2.7\%). Table 1 provides an overview of the annual leisure service expenditure and the portion of households that spent in the corresponding category.

Insert table 1 about here

Regarding the goodness of fit of a Tobit model type I, various pseudo- $\mathrm{R}^{2}$ statistics can be applied. Based on numerous Monte Carlo simulations, Veall and Zimmermann (1996) could detect that the pseudo- $\mathrm{R}^{2}$ by McKelvey and Zavoina (1975) is best suited to a direct comparison with the coefficient of determination $\left(\mathrm{R}^{2}\right)$ of the OLS estimations for the Tobit model type II and the linear model without correction of the sample selection. All in all, we estimated 54 (three per expenditure category) different regression models that show rather high variance explanatory power (values of $\mathrm{R}^{2}$ measure up to $52.47 \%$ ). This indicates that the set of selected determinants seems to be quite appropriate for explaining the German households' expenditure patterns on leisure services. 
Out of 54 coefficients, 46 show a highly significant impact of logarithmized total outlay on the analyzed expenditure shares. Amongst others, table 2 summarizes the conditional marginal effects that are based on these coefficients.

Insert table 2 about here

Interestingly, while the Tobit models type I indicate a significant positive impact of the logarithmized total outlay on the budget share, the other models indicate a significant negative one. This is the result of the contrary impact of logarithmized total outlay on the qualitative and the quantitative consumer decision: as the first step probit estimation results of the Tobit model type II verify, it appears that the logarithmized total outlay has a significant positive impact on the probability of consuming leisure services for all categories. Therefore, while the simultaneous Tobit models type I can only display the same sign for both decisions (qualitative, quantitative), the Tobit models type II could reveal a highly significant categoryindependent contrarian effect of logarithmized total outlay on the analyzed expenditure shares. Following equation 10, we can derive the category-specific expenditure elasticities based on the conditional marginal effects and the budget share. It is obvious that these model-specific differences between the estimation results have a considerable impact on the derived expenditure elasticities that are displayed on average for all households as well as for certain socio-demographic subgroups of households in table 3.

Insert table 3 about here 
Therefore, all the analyzed services (except LEISURE and CULTURE) are indicated as luxury goods $(\varepsilon>1)$ based on the findings of the Tobit model type I but as necessities $(0<\varepsilon<1)$ based on the findings of the Tobit model type II and the linear model without correction of the sample selection (see figure 3).

Insert figure 3 about here

\section{LIMITATIONS AND DIRECTIONS OF FURTHER RESEARCH}

In the above-described sections, we could derive expenditure elasticities for three aggregated categories and 15 subcategories of leisure services in Germany. The derivation is based on a consistent theoretical demand model with necessary and suitable extensions to consider the particularities in the field of leisure. Like many other studies on consumption expenditure, we are faced with the censored sample problem. To avoid biased estimates and elasticities, we applied different kinds of extended regression models. Obviously, we could see that the resulting expenditure elasticities are highly sensitive to the applied (censored) regression model. Due to the fact that Tobit models type I do not distinguish between the qualitative decision (whether or not to consume) and the quantitative decision (how much to spend), the resulting estimates are the same. This appears problematical, especially in the field of leisure service research, since we could detect that the logarithmized total outlay has a highly significant positive effect on the probability of consuming leisure services but a highly significant negative effect on the allocated budget share for the certain expenditure category. 
This leads to the striking question: which model is the right model? Due to the alreadydiscussed shortcomings of both models, it is not possible to present a first-best solution to this problem. One possible selection criterion might be the goodness of model fit (see table 2).

Indeed, for most of the expenditure categories, we could detect significant differences concerning the goodness of fit between the different model types. For five out of 18 expenditure categories (SPORT, MUSIC, SKI, MUSEUM, FILM), the Tobit model type I indicates the best goodness of fit value while there is a significantly higher value for the Tobit models type II for nine out of 18 expenditure categories (CULTURE, DANCE, FITNESS, OPERA, THEATER, CINEMA, CIRCUS, ZOO, PAYTV). Only four out of 18 expenditure categories (LEISURE, EVENT, POOL, CLUB) show a similar goodness of fit between the three different models. Given these empirical results, care should be taken with model selection and it seems at least advisable to estimate different model types and not jump to conclusions.

It would be desirable for further research to test whether similar consumption patterns exist for other services and in other countries. Furthermore, much effort should be put into the development and empirical validation of modified models that consider the censored sample problem in a reasonable way. 


\section{REFERENCES}

Amemiya, T. (1985) Advanced Econometrics, Basil Blackwell, Oxford.

Backhaus, K., Erichson, B., Plinke, W. \& Weiber R. (2006) Multivariate Analysemethoden - eine anwendungsorientierte Einführung, Springer, Berlin.

Barslund, M. C. (2007) Estimation of Tobit Type Censored Demand Systems: A Comparison of Estimators, Discussion Paper No. 07-16, Department of Economics, University of Copenhagen, Denmark.

Bittman, M. (1999) Social Participation and Family Welfare: The Money and Time Costs of Leisure, Discussion Paper No. 95, SPRC, Sydney.

Blaas, W. \& Sieber, L. (2000) Schätzung von direkten Preis-, Kreuzpreis- und Einkommenselastizitäten basierend auf einem vollständigen Konsummodell unter besonderer Berücksichtigung des Marktes alkoholfreier Getränke, Working Paper No. 1/2000, Institut für Finanzwissenschaft und Infrastrukturpolitik, Technische Universität Wien, Austria.

Blaine, T. W. \& Mohammad, G. (1991) An Empirical Assessment of U.S. Consumer Expenditures for Recreation-Related Goods and Services: 1946-1988, Leisure Sciences, 13 (2), 111-22.

Blundell, R., Browning, M. \& Meghir, C. (1994) Consumer Demand and the Life-Cycle Allocation of Family Expenditures, Review of Economic Studies, 61 (206), 57-80. 
Brosig, S. (2000) A Model of Household Type Specific Food Demand Behaviour in Hungary, Discussion Paper No. 30, Institut für Agrarentwicklung in Mittel- und Osteuropa, Halle.

Cai, L. A., Hong, G.-S. \& Morrison, A. M. (1995) Household Expenditure Patterns for Tourism Products and Services, Journal of Travel \& Tourism Marketing, 4 (4), 15-40.

Czarnitzki, D. \& Stadtmann, G. (2002) Uncertainty of Outcomes versus Reputation: Empirical Evidence for the First German Football Division, Empirical Economics, 27 (1), 10112.

Cooke, A. (1994) The Economics of Leisure and Sport, Routledge, New York.

Crouch, G. I. (1995) A Meta-Analysis of Tourism Demand, Annals of Tourism Research, 22 (1), 103-18.

Dardis, R., Soberon-Ferrer, H. \& Patro, D. (1994) Analysis of Leisure Expenditures in the United States, Journal of Leisure Research, 26 (4), 309-36.

Deaton, A. \& Muellbauer, J. (1980) An Almost Ideal Demand System, The American Economic Review, 70 (3), 312-26.

_ (1999) Economics of Consumer Behavior, University Press, Cambridge.

Department of the Arts, Sport, the Environment, Tourism and Territories (1988) The Economic Impact of Sport and Recreation - Household Expenditure, Technical Paper No. 1, Australian Government Publishing Service, Canberra.

Downward, P., Dawson, A. \& Dejonghe, T. (2009) Sports Economics - Theory, Evidence and Practice, Elsevier, Oxford. 
Eakins, J. M. \& Gallagher, L. A. (2003) Dynamic Almost Ideal Demand Systems: An Empirical Analysis of Alcohol Expenditure in Ireland, Applied Economics, 35 (9), $1025-36$.

Euler, M. (1990) Ausgaben privater Haushalte für Freizeitgüter, Wirtschaft und Statistik, 3, 219-27.

Fleck, M., \& Papastefanou, G. (2006) Einkommens- und Verbrauchstichprobe 1998 - Design und Methodik sowie Veränderungen gegenüber den Vorgängererhebungen, Arbeitsbericht Nr. 2006/01, ZUMA, Mannheim.

Franz, W. (2006), Arbeitsmarktökonomik, Springer, Berlin.

Geary, R. C. (1950-1951) A Note on 'A Constant Utility Index of the Cost of Living', Review of Economic Studies, 18, 65-66.

Gratton, C. \& Taylor, P. (1992) Economics of Leisure Services Management, $2^{\text {nd }}$ ed., Longman, Harlow.

Gratton, C. \& Taylor, P. (2000) Economics of Sport and Recreation, Spon Press, London.

Gundlach, E. (1993) Die Dienstleistungsnachfrage als Determinante des wirtschaftlichen Strukturwandels, Mohr, Tübingen.

Halvorsen, B. \& Nesbakken, R. (2004) Accounting for Differences in Choice Opportunities in Analyses of Energy Expenditure, Discussion Paper No. 400, Research Department, Statistics Norway, Oslo.

Heckman, J. (1974) Shadow Prices, Market Wages and Labor Supply, Econometrica, 42 (4), 679-94. 
(1976) The Common Structure of Statistical Models of Truncation, Sample Selection and Limited Dependent Variables and a Simple Estimator for Such Models, Annals of Economic and Social Measurement, 5 (4), 475-92.

_ (1979) Sample Selection Bias as a Specification Error, Econometrica, 47 (1), 153-61.

Heien, D. \& Wessells, C. R. (1990) Demand System Estimation with Microdata: A Censored Regression Approach, Journal of Business Economic Statistics, 8 (3), 365-71.

Henningsen, A. (2006) Modellierung von Angebots- und Nachfrageverhalten zur Analyse von Agrarpolitiken: Theorie, Methoden und empirische Anwendungen, Agrar- und Ernährungswissenschaftliche Fakultät, Christian-Albrechts-Universität, Kiel.

Hoffmann, R. \& Kassouf, A. L. (2005) Deriving Conditional and Unconditional Marginal Effects in Log Earnings Equations Estimated by Heckman's Procedure, Applied Economics, 37 (11), 1303-311.

Jones, T. (2004), Business Economics and Managerial Decision Making, Wiley, Chichester.

Katchova, A. L. \& Chern, W. S. (2004) Comparison of Quadratic Expenditure System and Almost Ideal Demand System Based on Empirical Data, International Journal of Applied Economics, 1 (1), 55-64.

Klein, L. R. \& Rubin, H. (1947-1948) A Constant-Utility Index of the Cost of Living, Review of Economic Studies, 15, 84-87.

Legohérel, P. \& Hong, K. K. F. (2006) Market Segmentation in the Tourism Industry and Consumers' Spending: What about Direct Expenditures? Journal of Travel and Tourism Marketing, 20 (2), 15-30. 
Leones, J., Colby, B. \& Crandall, K. (1998) Tracking Expenditures of the Elusive Nature Tourists of South-Eastern Arizona, Journal of Travel Research, 36 (3), 56-64.

Lera-López, F. \& Rapún-Gárate, M. (2005) Sports Participation versus Consumer Expenditure on Sport: Different Determinants and Strategies in Sport Management, European Sport Management Quarterly, 5 (2), 167-86.

Leser, C. E. V. (1963) Forms of Engel Functions, Econometrica, 31 (4), 694-703.

Lin, B.-H. (2006), A Sample Selection Approach to Censored Demand Systems, American Journal of Agricultural Economics, 88 (3), 742-49.

Lindberg, K. \& Aylward, B. (1999) Price Responsiveness in the Developing Country Nature Tourism Context: Review and Costa Rican Case Study, Journal of Leisure Research, 31 (3), 281-99.

Long, S. J. (1997) Regression Models for Categorical and Limited Dependent Variables, Sage, Thousand Oaks.

Loy, J. W. \& Rudman, W. J. (1983) Social Physics and Sport Involvement. An Analysis of Sport Consumption and Production Patterns by Means of Three Empirical Laws, S.A. Journal for Research in Sport, Physical Education and Recreation, 6 (2), 31-48.

Martin, W. H. \& Mason, S. (1980) Broad Patterns of Leisure Expenditure, The Sports Council and Social Science Research Council, London.

Matsuda, T. (2006) Linear Approximations to the Quadratic Almost Ideal Demand System, Empirical Economics, 31 (3), 663-75.

McDonald, J. F. \& R. A. Moffitt (1980) The Uses of Tobit Analysis, The Review of Economics and Statistics, 62, 318-87. 
McKelvey, R. \& Zavoina, W. (1975) A Statistical Model for the Analysis of Ordinal Level Dependent Variables, Journal of Mathematical Sociology, 4, 103-20.

Missong, M. (2004) Demographisch gegliederte Nachfragesysteme und Äquivalenzskalen für Deutschland, Duncker \& Humblot, Berlin.

Moehrle, T. (1990) Expenditure Patterns of the Elderly: Workers and Nonworkers, Monthly Labor Review, 113 (May), 34-41.

Nelson, J. P. (2001) Hard at Play! The Growth of Recreation in Consumer Budgets, 19591998, Eastern Economic Journal, 27 (1), 35-53.

Papanikos, G. T. \& Sakellariou, C. (1997) An Econometric Application of the Almost Ideal Demand System Model to Japan's Tourist Demand for ASEAN Destinations, Journal of Applied Recreation Research, 22 (2), 157-72.

Paulin, G. (1990) Consumer Expenditures on Travel, 1980-87, Monthly Labor Review, 113 (6), 56-60.

Pawlowski, T., Breuer, C., Wicker, P. \& Poupaux, S. (2009) Travel Time Spending Behavior in Recreational Sports: An Econometric Approach with Management Implications, European Sport Management Quarterly, 9 (3), 215-42.

Phlips, L. (1983) Applied Consumption Analysis, North-Holland, Amsterdam.

Pollak, R. A. \& Wales, T. J. (1992) Demand System Specification and Estimation, University Press, Oxford.

Pyo, S.-S., Uysal, M. \& McLellan, R. W. (1991) A Linear Expenditure Model for Tourism Demand, Annals of Tourism Research, 18 (3), 443-54. 
Salvatore, D. (2005) Introduction to International Economics, John Wiley \& Sons, Hoboken, New Jersey.

Samuelson, P. A. \& Nordhaus, W. D. (2001) Economics, McGraw-Hill, New York.

Shonkwiler, S. J. \& Yen, S. T. (1999) Two-Step Estimation of a Censored System of Equations, American Journal of Agricultural Economics, 81 (4), 972-82.

Sobel, M. E. (1983) Lifestyle Expenditures in Contemporary America, American Behavioral Scientist, 26 (4), 521-33.

Stone, R. J. N. (1954) Linear Expenditure Systems and Demand Analysis: An Application to the Pattern of British Demand, Economic Journal, 64, 511-27.

Tauchmann, H. (2005) Efficiency of Two-Step Estimators for Censored Systems of Equations: Shonkwiler \& Yen Reconsidered, Applied Economics, 37 (4), 367-74.

Thrane, C. (2001) Sport Spectatorship in Scandinavia. A Class Phenomenon? International Review for the Sociology of Sport, 36 (2), 149-63.

Tobin, J. (1958) Estimation of Relationships for Limited Dependent Variables, Econometrica, 26 (1), 24-36.

Van Ophem, J. \& de Hoog, K. (1994) Differences in Leisure Behaviour of the Poor and the Rich in the Netherlands, in Leisure: Modernity, Postmodernity and Lifestyles, Vol. I, (Ed.) I. Henry, The Leisure Studies Association, University of Brighton, pp. 291-305.

Veall, M. R. \& Zimmermann, K. F. (1996) Pseudo-R2 Measures for Some Common Limited Dependent Variable Models, Sonderforschungsbereich 386, Paper 18, LMU, München. 
Verbeek, M. (2005) A Guide to Modern Microeconometrics, $2^{\text {nd }}$ ed., Wiley, Chichester.

Wagner, F. \& Washington, V. R. (1982) An Analysis of Personal Consumption Expenditures as Related to Recreation, 1946-1976, Journal of Leisure Research, 14 (1), 37-46.

Weagley, R. O. \& Huh, E. (2004) Leisure Expenditures of Retired and Near-Retired Households, Journal of Leisure Research, 36 (1), 101-27.

Wolf, D. (2005) Ökonomische Sicht(en) auf das Handeln. Ein Vergleich der Akteursmodelle in ausgewählten Rational-Choice- Konzeptionen, Metropolis, Marburg.

Wooldridge, J. M. (2003) Introductory Econometrics. A Modern Approach, $2^{\text {nd }}$ ed., Thomson South-Western, Mason.

Working, H. (1943) Statistical Laws of Family Expenditure, Journal of the American Statistical Association, 38 (221), 43-56. 


\section{TABLES}

Table 1

Annual Leisure Service Expenditure (Source: CHBS, 2006; Own Calculations)

\begin{tabular}{|c|c|c|c|c|c|c|}
\hline \multirow[b]{2}{*}{$\#$} & \multirow[b]{2}{*}{$\begin{array}{c}\text { Service } \\
\text { category }\end{array}$} & \multicolumn{2}{|c|}{$\begin{array}{l}\text { Households with leisure } \\
\text { service expenditure }\end{array}$} & \multirow{2}{*}{$\begin{array}{l}\text { Total annual } \\
\text { expenditure } \\
\text { (million } €)^{\mathrm{a}}\end{array}$} & \multirow{2}{*}{$\begin{array}{c}\text { Mean annual } \\
\text { expenditure } \\
(€)^{\mathrm{b}}\end{array}$} & \multirow[b]{2}{*}{$\begin{array}{c}\text { Mean budget } \\
\text { share }^{c}\end{array}$} \\
\hline & & Number & Percentage & & & \\
\hline (1) & LEISURE & 7,513 & 97.3 & 25,100 & 312.0 & 3.105 \\
\hline (2) & SPORT & 5,362 & 69.4 & 11,100 & 255.5 & 1.832 \\
\hline (3) & CULTURE & 7,399 & 95.8 & 14,000 & 207.4 & 1.946 \\
\hline (4) & EVENT & 1,146 & 14.8 & 616 & 68.1 & .510 \\
\hline (5) & POOL & 1,667 & 21.6 & 706 & 48.6 & .406 \\
\hline (6) & MUSIC & 584 & 7.6 & 1,344 & 295.2 & 1.822 \\
\hline (7) & DANCE & 275 & 3.5 & 361 & 164.0 & 1.178 \\
\hline (8) & FITNESS & 643 & 8.3 & 1,279 & 253.3 & 2.118 \\
\hline (9) & SKI & 363 & 4.7 & 538 & 191.9 & 1.407 \\
\hline (10) & CLUB & 2,572 & 33.3 & 3,246 & 152.9 & 1.223 \\
\hline (11) & OPERA & 400 & 5.2 & 556 & 189.3 & 1.292 \\
\hline (12) & THEATER & 522 & 6.8 & 383 & 96.2 & .680 \\
\hline (13) & CINEMA & 1,993 & 25.8 & 646 & 40.4 & .330 \\
\hline (14) & CIRCUS & 199 & 2.6 & 121 & 61.1 & .487 \\
\hline (15) & MUSEUM & 2,184 & 28.3 & 633 & 37.8 & .280 \\
\hline (16) & ZOO & 754 & 9.8 & 254 & 42.1 & .322 \\
\hline (17) & PAYTV & 205 & 2.7 & 271 & 170.1 & 1.455 \\
\hline (18) & FILM & 346 & 4.5 & 73 & 25.4 & .203 \\
\hline
\end{tabular}

a "Total" refers to the total expenditure in Germany in 2006.

b "Mean" refers to the per capita expenditure of households with expenditure greater than zero.

c "Mean" refers to the mean budget share of households with expenditure greater than zero. 
Table 2

Goodness of Model Fit and Conditional Marginal Effects of Logarithmized Total Outlay

(Source: CHBS, 2006; Own Calculations)

\begin{tabular}{|c|c|c|c|c|c|c|c|}
\hline \multirow[b]{2}{*}{ \# } & \multirow{2}{*}{$\begin{array}{l}\text { Service } \\
\text { category }\end{array}$} & \multicolumn{3}{|c|}{$\begin{array}{l}\text { Goodness of } \\
\text { model fit }\end{array}$} & \multicolumn{3}{|c|}{$\begin{array}{l}\text { Conditional marginal effect of } \\
\text { logarithmized total outlay }\end{array}$} \\
\hline & & $\mathbf{T} \mathbf{I}$ & T II & OLS & T I & T II & OLS \\
\hline 1) & LEISURE & .90 & 5.43 & 5.30 & 0006759 & 0028992 & 3814 \\
\hline 2) & $\begin{array}{l}\text { SPORT } \\
\text { CULTURE }\end{array}$ & $\begin{array}{r}15.50 \\
6.70 \\
\end{array}$ & $\begin{array}{r}6.75 \\
10.65 \\
\end{array}$ & & $\begin{array}{r}.0035657 \\
-.0022585 \\
\end{array}$ & $\begin{array}{r}-.0041103 \\
-.0079035 \\
\end{array}$ & \\
\hline $\begin{array}{l}(4) \\
(5) \\
(6) \\
(7) \\
(8) \\
(9) \\
(10) \\
\end{array}$ & $\begin{array}{l}\text { EVENT } \\
\text { POOL } \\
\text { MUSIC } \\
\text { DANCE } \\
\text { FITNESS } \\
\text { SKI } \\
\text { CLUB } \\
\end{array}$ & $\begin{array}{l}10.70 \\
11.10 \\
28.40 \\
15.70 \\
11.80 \\
23.30 \\
10.20 \\
\end{array}$ & $\begin{array}{r}9.45 \\
11.63 \\
15.18 \\
27.49 \\
27.00 \\
20.18 \\
10.12 \\
\end{array}$ & & & $\begin{array}{l}-.0005241 \\
-.0028872 \\
-.0117653 \\
-.0064142 \\
-.0147181 \\
-.0031143 \\
-.0065077\end{array}$ & $\begin{array}{l}-.0005966 \\
-.0028810 \\
-.0087452 \\
-.0066614 \\
-.0145038 \\
-.0038634 \\
-.0065183 \\
\end{array}$ \\
\hline $\begin{array}{l}(11) \\
(12) \\
(13) \\
(14) \\
(15) \\
(16) \\
(17) \\
(18) \\
\end{array}$ & $\begin{array}{l}\text { OPERA } \\
\text { THEATER } \\
\text { CINEMA } \\
\text { CIRCUS } \\
\text { MUSEUM } \\
\text { ZOO } \\
\text { PAYTV } \\
\text { FILM } \\
\end{array}$ & $\begin{array}{l}11.60 \\
10.50 \\
17.30 \\
11.20 \\
11.20 \\
14.70 \\
13.80 \\
27.80 \\
\end{array}$ & $\begin{array}{r}17.94 \\
16.32 \\
20.14 \\
16.80 \\
6.98 \\
21.07 \\
52.47 \\
15.66 \\
\end{array}$ & $\begin{array}{r}14.42 \\
20.10 \\
16.08 \\
6.73 \\
21.06 \\
51.85 \\
14.85 \\
\end{array}$ & $\begin{array}{l}.0018995 \\
.0008289 \\
.0003173 \\
.0004309 \\
.0005324 \\
.0002648 \\
.0008341 \\
.0001546 \\
\end{array}$ & $\begin{array}{l}-.0066436 \\
-.0019656 \\
-.0023676 \\
-.0014026 \\
-.0011510 \\
-.0029747 \\
-.0086996 \\
-.0012159 \\
\end{array}$ & $\begin{array}{l}-.0066001 \\
-.0016553 \\
-.0023051 \\
-.0014058 \\
-.0012276 \\
-.0029648 \\
-.0091136 \\
-.0012974 \\
\end{array}$ \\
\hline
\end{tabular}

a "Goodness of model fit" refers to the pseudo- $R^{2}$ by McKelvey and Zavoina (1975) for the Tobit model type I and the coefficient of determination $\left(R^{2}\right)$ for the Tobit model type II and the linear model without correction of the sample selection.

b "Conditional marginal effect of logarithmized total outlay" refers to the estimated coefficient of the logarithmized total outlay for the linear model without correction of the sample selection and the transformed coefficient for the Tobit models type I (McDonald and Moffitt 1980) and II (Hoffmann and Kassouf 2005).

T I $\equiv$ Tobit model type I, T II $\equiv$ Tobit model type II, OLS $\equiv$ linear model without correction of the sample selection. 
Table 3

Demographical Scaled Expenditure Elasticities (Source: CHBS, 2006; Own Calculations)

\begin{tabular}{|c|c|c|c|c|c|c|c|c|c|c|c|c|c|c|c|}
\hline & \multicolumn{3}{|c|}{ LEISURE } & \multicolumn{3}{|c|}{ SPORT } & \multicolumn{3}{|c|}{ CULTURE } & \multicolumn{3}{|c|}{ EVENT } & \multicolumn{3}{|c|}{ POOL } \\
\hline & I & TII & OLS & I & - & $\mathbf{S}$ & T I & 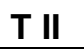 & 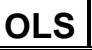 & T I & T II & OLS & T I & & OL \\
\hline$x$ & & 07 & & & & 90 & & & $.0<0$ & & . & |003. & & & \\
\hline city1 & 77 & 00 & & & & .780 & & & & & & & & & \\
\hline & & & & & 0 & 785 & & & & & & & & & \\
\hline & 30 & 2 & .852 & & .791 & .804 & & & .654 & & & & & & \\
\hline & & & & & .782 & .796 & & .572 & .605 & & .907 & & & 314 & \\
\hline & .979 & .910 & 19 & & 7 & .763 & & .649 & .676 & & .885 & .86 & & 247 & \\
\hline & .978 & .906 & .842 & & .783 & .797 & & .576 & .609 & & .893 & 078 & & & \\
\hline$q 1$ & .980 & & & & & .827 & & & .634 & & & $0-1$ & & & \\
\hline q & .978 & & & & & .800 & & & .616 & & & & & & \\
\hline ? & .978 & & & & & .767 & & & .629 & & .0 & .0 & & & 31 \\
\hline & .977 & & & & .73 & .752 & & & .623 & & & & & & \\
\hline & .986 & & & & .8 & .85 & & .690 & .714 & & .952 & .94 & & -.431 & -.42 \\
\hline & & & & & & .7 & & & & & & & & & \\
\hline & 81 & & & & .8 & .82 & & & .5 & & .8 & & & & \\
\hline & .979 & & & & $.7 \subseteq$ & .807 & & .5 & 6 & & .8 & & & & \\
\hline & .976 & & & & & $.7 !$ & & & .6 & & & & & & \\
\hline & .976 & & & & & .726 & & & .664 & & .860 & .84 & & 463 & \\
\hline & .979 & .910 & 818 & & .784 & .798 & & .528 & .564 & & .895 & .88 & & .242 & .2 \\
\hline & .980 & & & & & .819 & & .579 & 610 & & & & & $A$ & \\
\hline & & & & & & .771 & & & & & & & & &. \\
\hline & 6 & & & & & .75 & & & & & & & & & \\
\hline & 33 & .9 & & & .7 & .7 & & 3 & .7 & & .9 & & & .5 & \\
\hline & .978 & .90 & & & .7 & .7 & & .558 & .592 & & .897 & .8 & & 55 & \\
\hline & & & & & & .7 & & & .618 & & & & & 248 & \\
\hline & .977 & .9 & .8 & & .771 & .786 & & .507 & .545 & & .873 & .85 & & 172 & 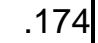 \\
\hline & .981 & & & & & .822 & & .649 & .676 & & .941 & & & & \\
\hline & .977 & & & & & .778 & & & & & & & & & \\
\hline & .981 & & & & & .8 & & & & & .8 & & & & \\
\hline & .977 & & & & & .7 & & & 5 & & .8 & & & & \\
\hline & & & & & & .79 & & & & & .925 & .9 & & & \\
\hline & & & & & & .7 & & & 5 & & 900 & .8 & & & \\
\hline & .97 & & & & & .7 & & .506 & .5 & & .892 & .8 & & 47 & \\
\hline & .981 & & .0 & & .8 & .828 & .8 & .483 & .523 & & .854 & .83 & & .047 & .04 \\
\hline Jpers & .981 & .511 & . & 1.151 & $.0<0$ & .838 & .822 & .378 & .42 & 1.245 & .810 & $7 \varepsilon$ & 1.110 & 029 & \\
\hline
\end{tabular}

T I इ Tobit model type I, T II $\equiv$ Tobit model type II, OLS $\equiv$ linear model without correction of the sample selection, $\varnothing \equiv$ average expenditure elasticity based on the subsample mean, / $\equiv$ not calculated due to data restrictions. 
Table 3 (Continued)

Demographical Scaled Expenditure Elasticities (Source: CHBS, 2006; Own Calculations)

\begin{tabular}{|c|c|c|c|c|c|c|c|c|c|c|c|c|c|c|c|}
\hline & \multicolumn{3}{|c|}{ MUSIC } & \multicolumn{3}{|c|}{ DANCE } & \multicolumn{3}{|c|}{ FITNESS } & \multicolumn{3}{|c|}{ SKI } & \multicolumn{3}{|c|}{ CLUB } \\
\hline & I & 7 & S & 1 & - & OLS & T I & $-\pi$ & s & 1 & & OLS & T I & 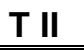 & OLS \\
\hline 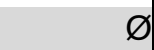 & & 54 & .520 & & & 435 & & & .315 & & & 12 & & & \\
\hline ity 1 & & 56 & 47 & & 5 & & & 5 & .315 & & .791 & .74 & & & \\
\hline & & 82 & 541 & & 0 & & & 278 & 289 & & .783 & & & & \\
\hline & & .467 & .604 & & 48 & & & .322 & .332 & & .747 & & & & \\
\hline & & .450 & .591 & & .421 & 398 & & 233 & .244 & & .782 & 25 & & & \\
\hline & & .376 & .536 & & .385 & .361 & & .309 & .319 & & .604 & 50 & & & \\
\hline & & 279 & .464 & & .501 & & & .350 & 250 أ & & .807 & 700 & & & 1 \\
\hline & & 302 & .481 & & & & & & .360 & & & & & & .5 \\
\hline & & 34 & & & & .35 & & & .403 & & & & & & .47 \\
\hline & & 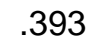 & & & & & & & 1 & & & & & & \\
\hline & & .360 & .524 & & .36 & 335 & & .2 & 282 & & & .483 & & & \\
\hline & 1 & I & 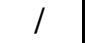 & 1 & I & 1 & & 5 & 528 & & 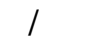 & & & & .0 \\
\hline & & 267 & .455 & & .49 & 480 & & .4 & .446 & & & .777 & & & \\
\hline & & .304 & .483 & & .37 & 35 & & .297 & .30 & & .8 & I & & 29 & .4 \\
\hline & & .409 & .561 & & .45 & 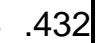 & & 293 & or & & .742 & 3 & & & \\
\hline & 1.036 & .511 & .637 & 1.071 & .506 & 487 & & 214 & .225 & & 631 & & & & \\
\hline & & .082. & & & .401 & .378 & & .291 & .30 & & .781 & .12 & & .4 & \\
\hline & & non & & & .409 & & & .248 & .25 & & .809 & & & & \\
\hline & & & & & & & & .248 & $.2 !$ & & & & & & \\
\hline & & - & & & .26 & & & .4 & & & & & & & .5 \\
\hline & 1.047 & .373 & .53 & 1.082 & .429 & .40 & & .248 & .259 & & .76 & .70 & & & .4 \\
\hline & & & 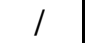 & & & & & .299 & 309 & & 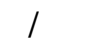 & 1 & & & 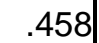 \\
\hline & 1.053 & 293 & .475 & & .516 & 497 & & .437 & .44 & & .739 & .676 & & & \\
\hline & & .345 & .513 & & .434 & 412 & & .261 & $.27 a^{\prime}$ & & .773 & .7 & & & \\
\hline & & 298 & .478 & & .339 & & & .079 & .092 & & .762 & & & & \\
\hline & & .549 & & & & & & & & & & & & & \\
\hline & & .03 & & & & & & .2 & & & & & & & \\
\hline & & عרנת & & & $x$ & $L$ & & & & & $.7 €$ & & & & \\
\hline & & 121 & 5 & & .30 & 281 & & -.039 & $\Omega$ & & .711 & & & .346 & 3 \\
\hline & & .506 & .6 & & .68 & .671 & & .512 & 5 & & .828 & 787 & & .602 & \\
\hline & & .473 & .608 & & & .476 & & & .21 & & .776 & $1<$ & & .4 & .46 \\
\hline & & .304 & .482 & & .417 & .39 & & .096 & .10 & & .717 & .64 & & .352 & .0 \\
\hline & & 268 & .4 & &.$<4$ & .20 & & .074 & .08 & & .793 & .744 & & .301 & \\
\hline & & .387 & & 1.121 & .153 & & 1. & .041 & & 88 & .672 & & 63 & .49 & \\
\hline
\end{tabular}

T I $\equiv$ Tobit model type I, T II $\equiv$ Tobit model type II, OLS $\equiv$ linear model without correction of the sample selection, $\varnothing \equiv$ average expenditure elasticity based on the subsample mean, / $\equiv$ not calculated due to data restrictions. 
Table 3 (Continued)

Demographical Scaled Expenditure Elasticities (Source: CHBS, 2006; Own Calculations)

\begin{tabular}{|c|c|c|c|c|c|c|c|c|c|c|c|c|c|c|c|}
\hline & \multicolumn{3}{|c|}{ OPERA } & \multicolumn{3}{|c|}{ THEATER } & \multicolumn{3}{|c|}{ CINEMA } & \multicolumn{3}{|c|}{ CIRCUS } & \multicolumn{3}{|c|}{ MUSEUM } \\
\hline & I & & $\mathbf{S}$ & T I & & OLS & T I & T II & OLS & T I & T I & OLS & T I & T II & OL \\
\hline$x$ & & & & & & & & & & & & 111 & & & \\
\hline ity 1 & & 70 & 4 & & 58 & 2 & & .182 & .204 & & & 582 & & & \\
\hline & & & & & 7 & .778 & & 6 & .276 & & & & & & \\
\hline & & & .562 & & & .792 & & .369 & .385 & & & & & & \\
\hline & & .486 & 489 & & & .728 & & 288 & .307 & & & .698 & & 12 & \\
\hline & & .411 & .415 & & .796 & 828 & & .339 & .356 & & & 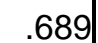 & & & \\
\hline & & .512 & & & & & & .245 & .265 & & & 78 & & & \\
\hline & & .47 & & & & 7 & & & .322 & & & + & & & \\
\hline & & .423 & & & & 722 & & & 279 & & & D & & & \\
\hline & & & 1 & & & & & 9 & & & & & & & \\
\hline & & .51 & .519 & &.$T_{c}$ & .767 & & 0 & & & & .700 & & & \\
\hline & 1 & l & / & 1 & I & / & & .658 & 667 & & 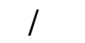 & & & & \\
\hline & & .67 & .674 & & .697 & .745 & & .407 & 4 & & & .732 & & & \\
\hline & & .271 & .276 & & .503 & 58 & & .289 & .30 & & & 87 & & & \\
\hline & & .50 & .511 & & .710 & .756 & & .241 & .26 & & & $3 s$ & & & \\
\hline & 1.135 & .528 & .532 & & .725 & 769 & & 192 & .213 & & & 5 & & .541 & \\
\hline & & .470 & .474 & & .787 & .820 & & .224 & .244 & & & .71 & & 24 & \\
\hline & & & & & .607 & & & .119 & & & & & & 99 & $\pi$ \\
\hline & & & & & 3 & & & .268 & .2 & & & & & & \\
\hline & & .25 & & & 3 & & & .434 & & & & & & & \\
\hline & 1.149 & .47 & .481 & & .763 & .800 & & .1 & & & & .70 & & & \\
\hline & & & 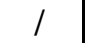 & & 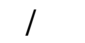 & 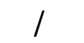 & & .707 & .714 & & & 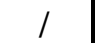 & & & .6 \\
\hline & 1.174 & & .394 & & .605 & 667 & & .291 & .30 & & & 0 & & 63 & \\
\hline & & .437 & .441 & & .685 & .735 & & .178 & .200 & & & .71 & & .606 & \\
\hline & 1.174 & .391 & 305 & & .656 & .710 & & .076 & 100 & & & 00 & & .561 & \\
\hline & & & & & & 7901 & & & & & & & & & \\
\hline & & & & & & .47 & & -.052 & & & & & & & \\
\hline & 1.234 & & & & .444 & 5 & & .125 & & & & & & & \\
\hline & & & .379 & & .682 & 7 & & .164 & & & .7 & .74 & & & \\
\hline & & .6 & .622 & & .773 & .80 & & & & & & 7 & & & \\
\hline & & .4 & .451 & & & 76 & & & & & & 74 & & 78 & \\
\hline & & .38 & .393 & & .632 & .690 & & .073 & $.0 s$ & & .6 & 69 & & .600 & .57 \\
\hline & & .3 & & & .516 & .5 & & .0 & .08 & & & $.67 s$ & & .492 & \\
\hline & & & & 9 & .314 & & 4 & .003 & & 84 & .400 & .399 & 1.237 & .487 & \\
\hline
\end{tabular}

T I $\equiv$ Tobit model type I, T II $\equiv$ Tobit model type II, OLS $\equiv$ linear model without correction of the sample selection, $\varnothing \equiv$ average expenditure elasticity based on the subsample mean, / $\equiv$ not calculated due to data restrictions. 
Table 3 (Continued)

Demographical Scaled Expenditure Elasticities (Source: CHBS, 2006; Own Calculations)

\begin{tabular}{|c|c|c|c|c|c|c|c|c|c|}
\hline & \multicolumn{3}{|c|}{ ZOO } & \multicolumn{3}{|c|}{ PAYTV } & \multicolumn{3}{|c|}{ FILM } \\
\hline & | & II & OLS & T I & T II & OLS & T I & T II & OLS \\
\hline$\varnothing$ & 1.082 & .075 & .078 & 1.057 & .402 & .374 & 1.076 & .401 & .36 \\
\hline city1 & & .015 & 018 & 1.056 & .416 & .388 & 1.070 & .446 & .40 \\
\hline & & -.0 & & 1. & .390 & .361 & & .218 & .16 \\
\hline & & .190 & & & .385 & .355 & & .437 & 39 \\
\hline nort & 1.072 & .186 & & & .308 & .275 & & .393 & \\
\hline & 1.081 & .094 & & 1.055 & .422 & .394 & & .427 & \\
\hline ed & 1.092 & -.035 & -.031 & 1.054 & .438 & .411 & 1.076 & .399 & .358 \\
\hline$q 1$ & 1.082 & .083 & .086 & 1.058 & .391 & .362 & 1.076 & .401 & .361 \\
\hline q2 & 1.087 & .028 & 031 & 1.053 & .448 & .422 & 1.075 & .408 & .36 \\
\hline q3 & 1.079 & .117 & 120 & 1.061 & .359 & .329 & 1.074 & .416 & 377 \\
\hline$q 4$ & 1.085 & .050 & .053 & 1.057 & .406 & .378 & 1.079 & .381 & .33 \\
\hline age25 & 1 & 1 & / & 1 & 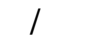 & / & 1.079 & .381 & 33 \\
\hline & 1.050 & .441 & .443 & 1.063 & .347 & .316 & & .560 & .53 \\
\hline & & -.0 & & & .309 & .276 & & 432 & .39 \\
\hline & & -.097 & -.0 & & .383 & .354 & & .325 & .280 \\
\hline & & .213 & .215 & & .449 & .423 & & .123 & .06 \\
\hline & 1.078 & .121 & .124 & 1. & .538 & .516 & & .389 & .34 \\
\hline & 1.125 & -.400 & -.396 & 1.079 & .172 & .133 & 77 & .396 & .356 \\
\hline & 1.088 & .016 & .019 & 1.084 & .124 & .082 & 74 & .420 & .381 \\
\hline & 1.079 & .112 & .115 & 1.035 & .636 & $.61 \xi$ & 30 & .368 & .326 \\
\hline & 1. & .083 & 0 & 1.047 & .510 & .487 & & .337 & .29 \\
\hline & & . 157 & .16 & & I & / & & .503 & .47C \\
\hline & 1.069 & .220 & .22 & 1.0 & .455 & .429 & & 359 & 31 \\
\hline & 1.0 & .072 & .0 & & .058 & .013 & & .373 & .33 \\
\hline $\mathrm{m}$ & 1.082 & .080 & .08 & 1.068 & .293 & .259 & 15 & .098 & .037 \\
\hline & 1.104 & -.173 & -.16 & 1.046 & .519 & .49 & 56 & .559 & .530 \\
\hline & 1.075 & .15 & .161 & 1.057 & .404 & .37 & 45 & -.143 & -.210 \\
\hline 18 & 1.089 & -.00 & -.00 & 1.091 & .046 & .000 & 26 & .010 & -.05 \\
\hline & & & -.1 & & 224 & .18 & & .356 & .313 \\
\hline & 1.077 & .136 & 1 & & .587 & .567 & & .597 & .57 \\
\hline & 1.082 & .074 & .0 & & .396 & .36 & & .389 & .34 \\
\hline & 1.093 & .049 & -.0 & & .264 & .22 & & .124 & .06 \\
\hline & 1.074 & .17 & .1 & & .186 & .14 & & -.010 & -.077 \\
\hline 5 & 1.116 & 0 & & 1.078 & .188 & & 1.112 & 118 & 05 \\
\hline
\end{tabular}

T I $\equiv$ Tobit model type I, T II I Tobit model type II, OLS $\equiv$ linear model without correction of the sample selection, $\varnothing \equiv$ average expenditure elasticity based on the subsample mean, / $\equiv$ not calculated due to data restrictions. 


\title{
FIGURES
}

\author{
FIGURE 1
}

INTERDEPENDENCIES BETWEEN UTILITY MAXIMIZATION AND COST MINIMIZATION (SOURCE: DEATON AND MUELLBAUER, 1999, 38)

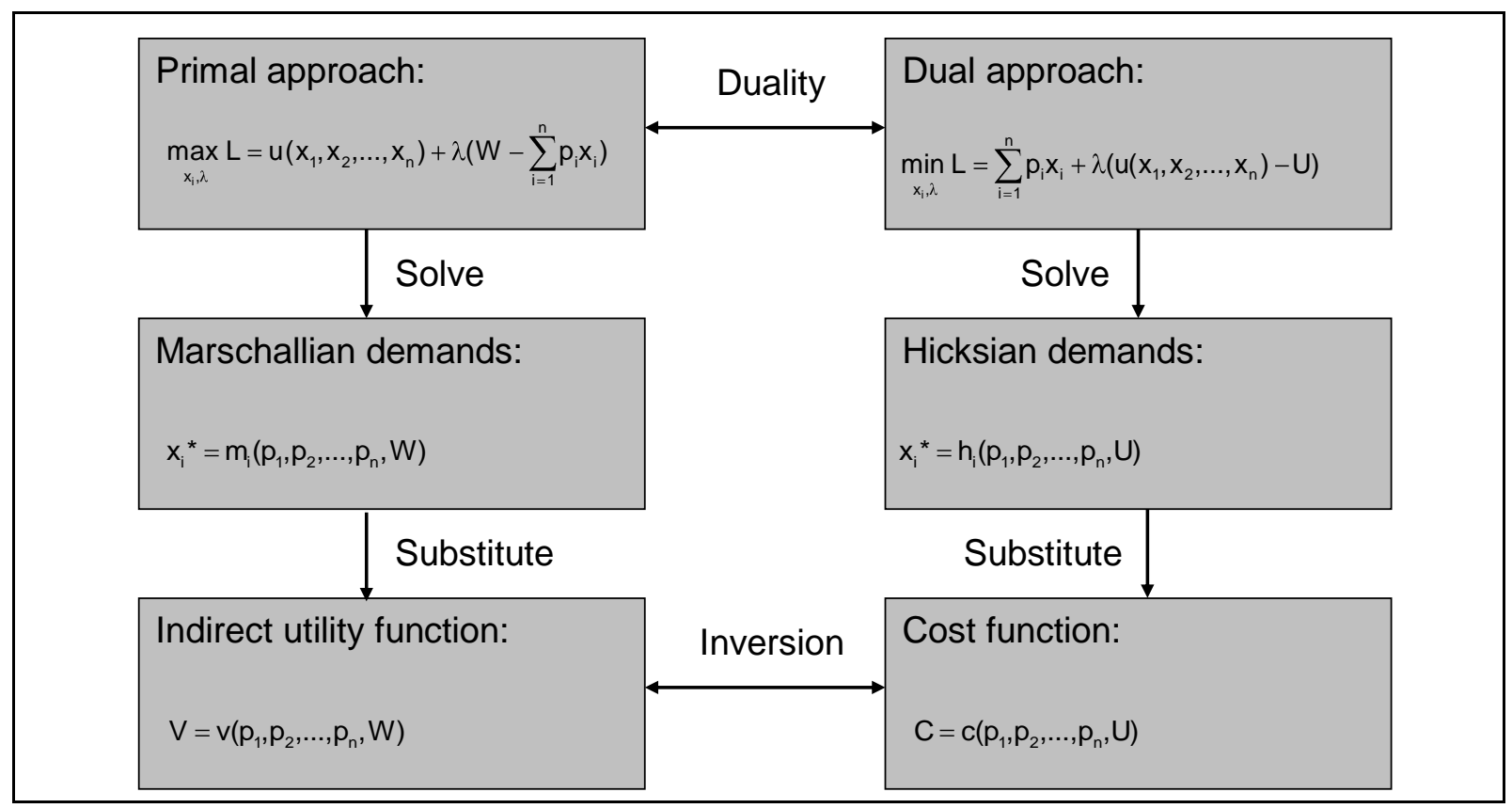


FIGURE 2

DISTRIBUTION OF LEISURE OPPORTUNITIES (BASED ON BITTMAN, 1999)

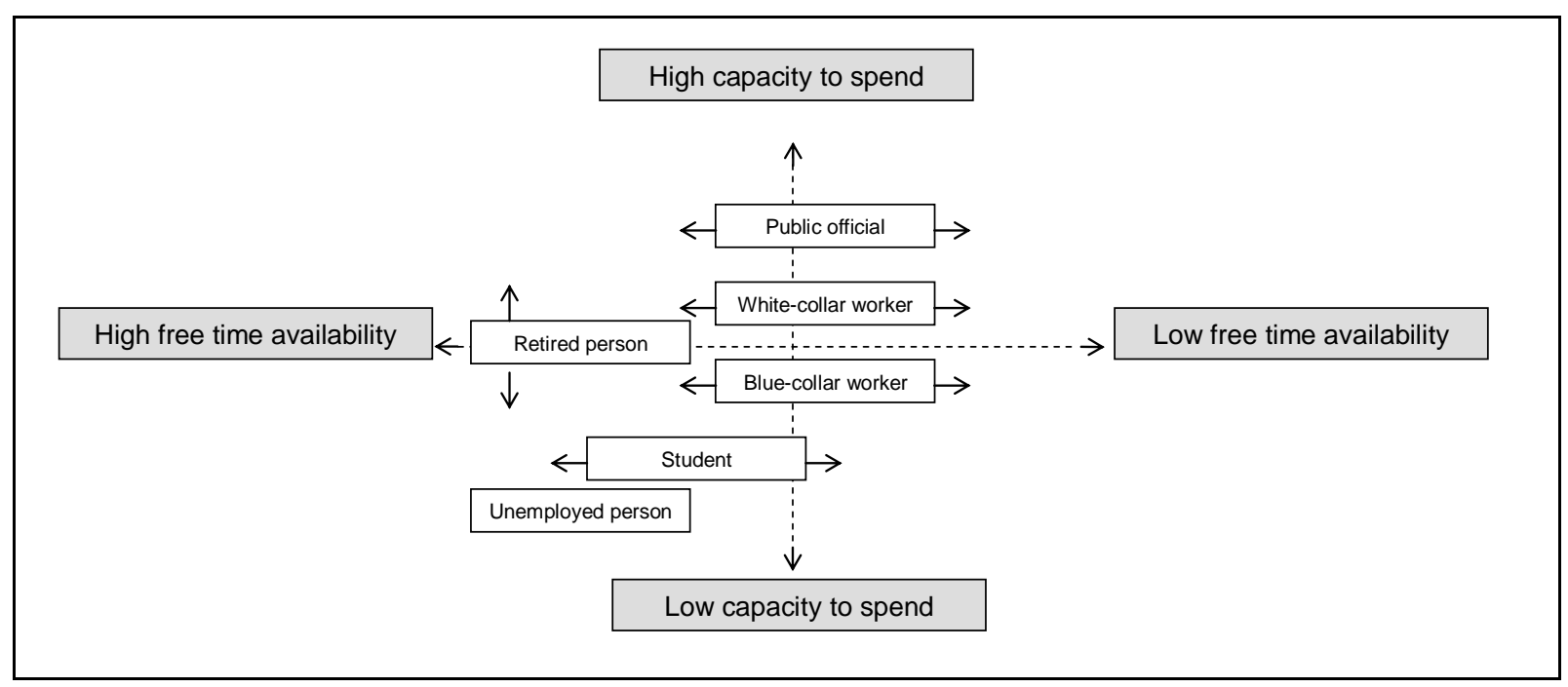


FIGURE 3

CONDITIONAL EXPENDITURE ELASTICITIES FOR LEISURE SERVICES AND THEIR SUBCATEGORIES (SOURCE: CHBS, 2006; OWN CALCULATIONS)

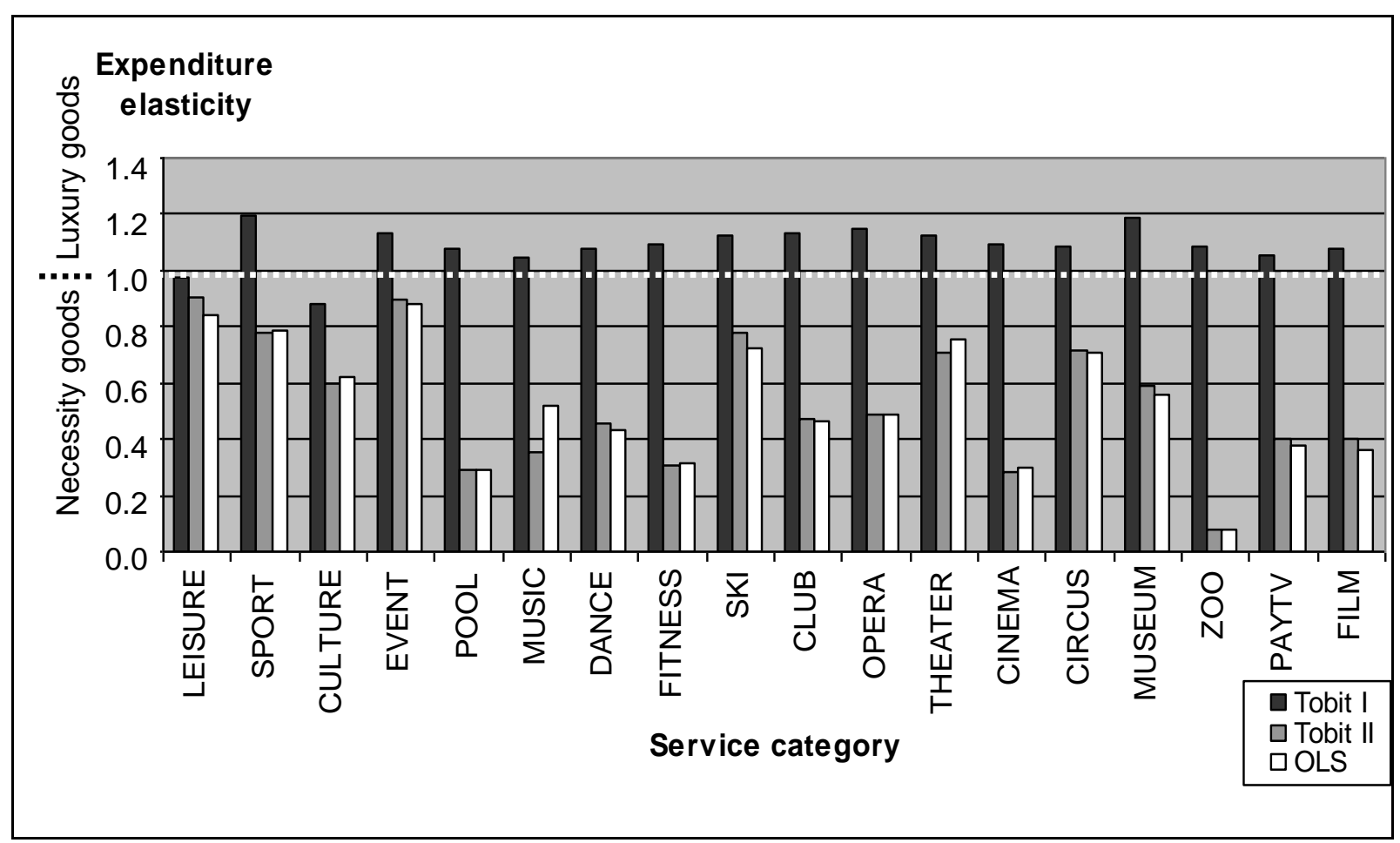

